\title{
Correction to: Postmaterialism and the Perceived Quality of Elections: A Study of the Moderation Effect of a Critical Event
}

\section{Gary Tang $^{1}$ (D) Edmund W. Cheng $^{2}$ (D)}

Published online: 25 July 2021

(c) Springer Nature B.V. 2021

\section{Correction to: Social Indicators Research (2021) 155:335-354 https://doi.org/10.1007/s11205-020-02599-y}

In the original publication of this article, the funding information section has been missed to publish. Now the same has been provided in this correction.

Funding Information: This research was supported by the General Research Fund, University Grant Committee, Hong Kong (ref. 14606216).

Publisher's Note Springer Nature remains neutral with regard to jurisdictional claims in published maps and institutional affiliations.

The original article can be found online at https://doi.org/10.1007/s11205-020-02599-y.

Gary Tang

garytang@hsu.edu.hk

Edmund W. Cheng

ew.cheng@cityu.edu.hk

1 Department of Social Science, The Hang Seng University of Hong Kong, Shatin, Hong Kong SAR, China

2 Department of Public Policy, City University of Hong Kong, Kowloon Tong, Hong Kong SAR, China 